\title{
MENINGKATKAN LITERASI MELALUI BAHAN AJAR TEMATIK SAINTIFIK BERBASIS KEARIFAN LOKAL
}

\author{
Nuhyal Ulia ${ }^{1}$, Yulina Ismiyanti ${ }^{2}$, Leli Nisfi Setiana ${ }^{3}$ \\ UUniversitas Islam Sultan Agung \\ email: nuhyalulia@unissula.ac.id \\ ${ }^{2}$ Universitas Islam Sultan Agung \\ email: yulinaismiyanti@unissula.ac.id \\ UUniversitas Islam Sultan Agung \\ email: lelinisfi@unissula.ac.id
}

\begin{abstract}
The literacy movement is being carried out by the government nationally in various circles ranging from families, schools and communities. It is also entitled to be felt by all people including street children. For street children literacy culture also needs to be grown because their literacy is still low. This effort was carried out by increasing literacy in "Lotus" street children in the Social Barracks of Demaan Village, Kudus Regency, Central Java. Lack of interest in learning because teaching materials in schools are not easy for them to digest, making them less desirable and a burden on them. Teaching materials that are made thematically presented in the form of reading about local wisdom around them are expected to improve their literacy culture. The PKM is carried out by mentoring educational programs in the form of tutoring and training in improving literacy. In mentoring using teaching materials that have been developed by applying several methods. Like learning methods based on study groups according to age with approaches such as scientific, thematic, tutorial, drill and lecture. while the implementation of literacy training delivered good reading and writing methods. From this PKM activity, it was found that the level of enthusiasm of attendance was very high $\% 80 \%$, literacy ability had experienced an increase of $>10 \%$ with a significant.
\end{abstract}

Keywords: Street Children; Literacy; Scientific thematic teaching material; local wisdom

\begin{abstract}
ABSTRAK
Gerakan literasi sedang gencar digalakkan pemerintah secara nasional di berbagai kalangan mulai di lingkungan keluarga, sekolah dan masyarakat. Hal tersebut juga berhak dirasakan oleh semua kalangan termasuk anak jalanan. Bagi anak jalanan budaya literasi juga perlu ditumbuhkan melihat kenyataan bahwa kemampuan baca tulis mereka masih rendah. Upaya nyata tersebut dapat dilakukan dengan meningkatkan literasi pada POKJA anak jalanan "Teratai" di Barak Sosial Desa Demaan Kabupaten Kudus Jawa Tengah. Kurang tertariknya terhadap pembelajaran salah satunya karena mereka merasa bahan ajar di sekolah tidak mudah mereka cerna, sehingga tidak diminati dan cenderung berat bagi mereka. Bahan ajar yang dibuat berbentuk tematik disajikan dalam bentuk bacaan tentang kearifan lokal yang ada disekitar mereka dan diharapkan dapat meningkatkan budaya literasi mereka.
\end{abstract}


Adapun PKM yang dilakukan adalah pendampingan program pendidikan berupa bimbingan belajar dan pelatihan dalam meningkatkan literasi. Dalam pendampingan menggunakan bahan ajar yang sudah dikembangkan dengan menerapkan beberapa metode. Seperti metode pembelajaran berbasis kelompok belajar sesuai usia dengan pendekatan seperti saintifik, tematik, tutorial, drill dan ceramah sedangkan pada pelaksanaan pelatihan literasi disampaikan metode membaca dan menulis yang baik. Dari kegiatan PKM ini diperleh bahwa tingkat antusias kehadiran sangat tinggi $\geq 80 \%$, kemampuan literasi sudah mengalami kenaikan > 10\% dengan kenaikan yang signifikan.

Kata Kunci: anak jalanan; literasi; bahan ajar tematik saintifik; kearifan lokal

\section{PENDAHULUAN}

POKJA anak jalanan "Teratai" di Barak Sosial Desa Demaan Kabupaten Kudus merupakan sebuah komunitas yang menampung anak jalanan dari berbagai usia. Berdasarkan data yang diperoleh anggota kelompok tersebut terdiri dari 30 Anggota dan 20 anggota dari mereka masih dalam usia sekolah. Ada sekitar 10 usia produktif. Di antara 30 anak ada sekitar $45 \%$ yang putus sekolah. Alasan mereka putus sekolah bermacammacam. Berdasarkan wawancara yang dilakukan terhadap ketua kelompok Ibu Romdhonah mengatakan bahwa mereka banyak yang putus sekolah dikarenakan faktor ekonomi. Walaupun sudah ada BOS disekolah dengan sekolah gratis, namun mereka masih memikirkan ekonomi keluarga. Biaya hidup sehari-hari, tuntutan kebutuhan di keluarganya bahkan karena faktor lingkungan dengan alasan ikut-ikutan karena pengaruh teman-temannya. Mereka saling mengajak untuk bekerja dan hidup di jalanan. Selain faktor ekonomi, alasan putus sekolah dikarenakan ketidaktertarikan mereka terhadap pendidikan karena tingkat pendidikan orang tua yang masih rendah bahkan tidak sekolah. Hal ini sebagaimana hasil penelitian Yunda ,P (2010) yang menyatakan bahwa faktor ekonomi dan tingkat pendidikan orang tua menjadi faktor penyebab putus sekolah anak-anak jalanan. Hasil wawancara tentang alasan mengapa mereka turun ke jalan diperoleh beberapa alasan seperti karena alasan ekonomi, mereka mempunyai tujuan untuk membantu biaya hidup keluarganya. Alasan lainnya adalah untuk memperoleh tambahan uang jajan atau uang saku. Adapu alasan lainnya mereka turun ke jalan hanya untuk hiburan atau rekreasi sehingga mereka dapat berkumpul dengan teman-temannya dan sebagai ajang penyaluran hobi untuk bermusik.

POKJA anak jalanan "Teratai" berada di sebuah Barak sosial yang beralamat di Desa Dema'an Rt:04 Rw:04 merupakan sebuah lokasi yang sangat strategis. Berada di lokasi bantaran sungai "Kaligelis", berjarak dekat dengan jalan raya di area simpang tujuh kabupaten Kudus, dan dekat juga dengan Komplek Wisata Menara Kudus. Terlebih lagi, di dukung dengan event-event khusus kegiatan tradisi seperti tradisi "Buka Luwur", tradisi "Dhandangan" yang diselenggarakan disekitar daerah tersebut tentunya hal ini membuat komunitas Barak Sosial betah dan merasa cocok tinggal di tempat tersebut. Pernah terjadi pada tahun 2010 Barak Sosial melalui Pemerintah 
Daerah di pindah di Desa Hadipolo Kecamatan Jekulo Kudus. Namun, mereka tidak betah dan merasa tidak nyaman karena dianggap kurang strategis bagi mereka sehingga secara berangsur-angsur mereka kembali ke Barak semula.

Keberadaan kelompok ini tetap diperhatikan oleh pemerintah terutama Pemerintah Desa Demaan. Beberapa kegiatan sudah banyak di lakukan oleh POKJA anak jalanan "Teratai" di Barak Sosial Desa Demaan seperti pelatihan ketrampilan menjahit, bengkel dan lain-lain. Kegiatan-kegiatan yang dilakukan hanya sebatas pada vokasional saja. Dengan tujuan untuk ketrampilan kerja nantinya. Dengan demikian, sangat ironis sekali di saat banyak yang putus sekolah namun kegiatan di POKJA anak jalanan "Teratai" belum ada penyelenggaraan program pendidikan. Sehingga setelah mereka menjalani pelatihan ketrampilan mereka kembali berkeliaran di jalan raya. Padahal pendidikan sangat penting bagi mereka. Dengan pendidikan mereka akan mendapat pengetahuan dasar yang sangat berguna bagi kehidupan mereka.

Jika ada program pendidikan yang diberikan di POKJA anak jalanan "Teratai" mereka akan memperoleh pengetahuan dasar selain dapat membantu sebagai bimbingan belajar bagi yang masih sekolah. Dan sesuai dengan pendapat Ajisuksmo, C. R (2012) yang mengatakan bahwa pengetahuan dasar akan sangat berguna bagi siswa yang putus sekolah untuk bekal mengikuti pendidikan luar sekolah seperti pendidikan Paket $A / B / C$ Walaupun dengan pendidikan paket $\mathrm{A} / \mathrm{B} / \mathrm{C}$ mereka dapat mempergunakannya untuk mencari pekerjaan yang lebih layak atau lebih baik dan bahkan dapat digunakan untuk melanjutkan ke jenjang pendidikan yang lebih tinggi. Dan hal ini akan dapat meningkatkan kualitas derajat kehidupan mereka.

Perhatian kelompok anak jalanan "Teratai" di Barak Sosial Desa Demaan terhadap pendidikan masih rendah. Hal ini ditunjukkan ketika melakukan wawancara terhadap mereka ternyata ada yang tidak mau melanjutkan sekolah dikarenakan belum bisa membaca walaupun sudah berkali-kali belajar. Ketika kami berikan pertanyaan dengan tes sederhana tentang literasi berupa baca tulis mereka banyak yang belum mampu menyelesaikan. Pemahaman mereka terhadap bacaan masih sangat kurang. Kemampuan membaca masih mengeja, bahkan anak di usia SD kelas 1 dan 2 masih ada yang belum lancar membaca. Kemampuan menulis juga demikian. Tulisan yang mereka kerjakan masih belum rapi, masih muncul huruf-huruf yang terbalik, demikian juga untuk anak di usia kelas tinggi, mereka belum mampu menulis sesuai dengan EYD. Diantara mereka ada yang mengatakan karena pendidikan di sekolah di rasa berat untuk difahami, mereka merasa tidak mampu memahami buku-buku yang diberikan. Ketika sudah pulang dari sekolah mereka tidak sempat untuk mengulang pelajaran dan mempelajarinya karena harus turun di jalan untuk mencari uang.

"Gerakan Nasional Literasi Bangsa (GNLB)" sebagai gerakan literasi yang digencarkan oleh pemerintah secara nasional di berbagai kalangan seperti keluarga, sekolah dan masyarakat. Hal ini sesuai dengan 
Permendikbud No.23 Tahun 2015 tentang pentingnya membuat program unggulan bernama "Gerakan Nasional Literasi Bangsa (GLB)" yang mempunyai tujuan untuk menumbuhkan karakter atau budi pekerti melalui membaca dan menulis atau disebut dengan budaya literasi (2016). Budaya literasi tersebut harus segera ditanamkan kepada anak karena kegemaran membaca seorang anak sangat dipengaruhi pada saat pembelajaran. Apabila seorang anak tersebut sudah gemar membaca sejak dini, maka kegemaran tersebut diyakini akan terbawa sampai dewasa.

Pentingnya literasi ditumbuhkan pemerintah karena dilatar belakangi oleh hasil penelitian Programme for International Student Assessment (PISA) disebutkan bahwa budaya literasi masyarakat Indonesia pada tahun 2015 menempati urutan 62 dari 70 negara partisipan dalam penelitian yang dilakukan oleh PISA dengan nilai mean score sebesar 386. Dengan demikian disimpulkan kemampuan literasi masyarakat Indonesia masih rendah (Tohir,M \& Jember, 2016). Sementara itu, pada tahun 2012 tercatat bahwa indeks minat baca di Negara Indonesi hanya mencapai 0,001 yang berarti bahwa setiap seribu penduduk Indonesia hanya terdapat 1 orang saja yang mempunyai minat baca, hal ini sesuai dengan data statistik UNESCO.

Dengan demikian, dalam rangka mensukseskan gerakan literasi di berbagai kalangan termasuk juga untuk kelompok anak jalanan maka perlu dilakukan kegiatan-kegiatan dalam rangka meningkatkan literasi. Budaya literasi di POKJA anak jalanan "Teratai" di Barak Sosial Desa Demaan belum ditumbuhkan dengan baik. Kegiatan dalam rangka menumbuhkan minat baca dan tulis belum terfasilitasi dengan baik. Kegiatan-kegiatan yang sudah diadakan belum mengarah pada kegiatan dalam meningkatkan literasi. Seperti tidak adanya buku-buku cerita atau perpustakaan kecil atau pojok baca sebagai sarana yang mendukung literasi. Bahkan sempat waktu wawancara terhadap beberapa anak jalanan tentang literasi mereka belum mengenal budaya literasi, bahkan mayoritas dari mereka tidak suka membaca karena berbagai alasan seperti masih ada yang belum lancar baca tulis, membaca membosankan, membuang-buang waktu. Mereka lebih tertarik untuk mencari uang daripada hanya sekedar membaca. Selain itu, ada yang beralasan mereka tidak mempunyai buku-buku bacaan yang menarik untuk dibaca. Oleh karena itu, perlu dikenalkan, ditumbuhkan dan dilatih budaya literasi di POKJA anak jalanan "Teratai" di Barak Sosial Desa Demaan dalam rangka mendukung program pemeritah untuk mensukseskan "Gerakan Literasi Bangsa".

Dalam rangka meningkatkan literasi di POKJA anak jalanan "Teratai" di Barak Sosial Desa Demaan tentunya diperlukan suatu bahan ajar sebagai sarananya. Diperlukan bahan ajar yang sesuai dengan karakteristik dan minat mereka. Bahan ajar tematik saintifik merupakan bahan ajar yang disusun berdasarkan tema-tema tertentu dan menggunakan pendekatan Saintifik sebagai pendekatan yang membuat aktif pembelajaran. Bahan ajar Tematik Saintifik yang akan digunakan berbasis literasi yang kontennya akan 
disesuaikan dengan kearifan lokal yang ada di lingkungan POKJA anak jalanan "Teratai" di Barak Sosial Desa Demaan. Sajian bahan ajar ini akan memacu mereka untuk membaca dan dalam bacaan yang mana tema yang disajikan mengangkat kearifan lokal seperti sejarah Menara Kudus, tradisi masyarakat di lingkungan menara, prosesi Dhandangan, Tradisi Bukak Luwur dan berbagai kegiatan yang sering dimanfaatkan oleh kelompok anak jalanan "Teratai" di Barak Sosial Desa Demaan.

Kegiatan yang akan dilakukan pada PKM ini adalah mengadakan program-program di bidang pendidikan. Sebagai contoh mengadakan bimbingan belajar bagi anak-anak jalanan di usia sekolah yang mana dalam kegiatan ini akan disampaikan pembelajaran inovatif seperti outing class, mengadakan sosialisasi budaya literasi, mengadakan kegiatan dalam rangka menumbuhkan budaya literasi seperti pembiasaan baca tulis, mengaji/ baca tulis Al qur'an, event lomba mengarang dan sebagainya, mengadakan pojok baca seperti perpustakaan mini dengan buku-buku referensi yang mendidik, mengadakan pendampingan belajar dengan bahan ajar tematik saintifik berbasis kearifan lokal. Melalui kegiatan-kegiatan ini PKM bertujuan dapat meningkatkan ketrampilan literasi pada POKJA anak jalanan "Teratai" di Barak Sosial Desa Demaan Kabupaten Kudus.

Berdasarkan analisis situati diatas, maka permasalahan yang ditemukan pada mitra adalah sebagai berikut. 1) POKJA anak jalanan "Teratai" di Barak Sosial Desa Demaan belum memperhatikan pendidikan terlihat belum adanya pelaksanaan program di bidang pendidikan. Selama ini kegiatan yang mereka lakukan hanya berorientasi pada ketrampilan vokasional saja. 2) Perlunya meningkatkan budaya literasi pada kelompok anak jalanan "Teratai" di Barak Sosial Desa Demaan dikarenakan mereka belum memiki jiwa budaya literasi, memahami manfaat budaya literasi bagi perkembangan membaca dan menulis sebagai dasar dalam berkomunikasi. Dan mengingat pentingnya keterampilan membaca dan menulis merupakan hal yang mendasar dan penting bagi keberlangsungan komunikasi dalam kehidupan sehari-hari. 3) Belum adanya bahan ajar yang sesuai dengan kebutuhan, karakteristik dan kearifan lokal kelompok anak jalanan "Teratai" di Barak Sosial Desa Demaan dalam meningkatkan ketrampilan literasi.

\section{METODE PELAKSANAAN}

Berdasarkan rumusan permasalahan yang telah disebutkan, dapat diberikan beberapa solusi diantaranya 1) adanya program pendidikan pada POKJA anak jalanan "Teratai" di Barak Sosial Desa Demaan Kabupaten Kudus yang didalam program tersebut terdapat kegiatan-kegiatan tentang pendidikan seperti bimbingan belajar, outing kelas. 2) Diadakannya kegiatan pembelajaran dan pelatihan di POKJA anak jalanan "Teratai" di Barak Sosial Desa Demaan dalam menumbuhkan pemahaman tentang budaya literasi dalam rangka pengembangan baik dalam membaca, menulis, berbahasa dan berkomunikasi dan mengarah pada literasi sehingga budaya literasi dapat 
ditumbuhkan pada kelompok ini. 3) Dikembangkannya bahan ajar tematik saintifik berbasis kearifan lokal agar menarik bagi mereka dalam meningkatkan kemampuan literasi karena sudah disesuaikan dengan karkteristik mereka.

Pelaksanaan pengabdian yang dilakukan melalui beberapa tahap. Tiap tahan memiliki metode yang berbeda. Adapun tahap-tahap dan metode dalam pelaksanaan pengabdian diantaranya 1) Sosialisai, pada tahap ini bertujuan memberikan pemahaman tentang kegiatan PKM, sosialisasi tentang pentingnya literasi bagi anak, sosialisasi tentang pentingnya pendidikan bagi anak jalanan agar mereka termotivasi untuk selalu bersekolah. Kegiatan sosialisasi dilakukan dengan metode ceramah, motivasi, dan diskusi. 2) Peningkatan kompetensi, pada tahap ini kompetensi yang akan ditingkatkan adalah kemampuan literasi yaitu kemampuan membaca, menulis dan pemahaman pada bacaan. Kegiatan yang dilakukan pada tahap ini berupa pendampingan melalui bimbingan belajar. Metode yang digunakan sangatlah komplek dan variatif. Seperti metode ceramah, demonstrasi, tutorial, Tanya jawab, diskusi, tematik, pendekatan saintifik dan outing class. 3) Pelaksanaan kegiatan berupa pelatihan. Pelatihan yang diadakan adalah pelatihan literasi dengan menerapkan metode demontrasi, tutor sebaya atau learning by doing. Anak di berikan semacam materi menulis dan membaca untuk kemudian d praktekkan. 4) Monitoring dan evaluasi. Dalam tahap ini merupakan tahap bukan dimaksudkan tahap terkahir namun pelaksanaannya tetap dilakukan di setiap tahap sebelumnya. Pada kegiatan monitoring dan evaluasi dilakukan dengan metode observasi dan wawancara.

Dalam melaksanakan pemecahan permasalahan, dikembangkan bahan ajar tematik saintifik berbasis kearifan lokal dengan beberapa pendekatan yang dilakukan secara bersama-sama yaitu: 1) Berbasis kelompok belajar, seluruh kegiatan pengabdian masyarakat dilakukan kepada masyarakat dengan menggunakan POKJA anak jalanan "Teratai" di Barak Sosial Desa Demaan Kabupaten Kudus sebagai media belajar dan pendampingan, perencanaan dan memonitor serta evaluasi seluruh kegiatan pengabdian masyarakat. 2) Komprehensif, seluruh kegiatan pengabdian masyarakat dilakukan secara serentak terkait dengan SDM, proses belajar, publikasi melalui pelatihan, sosialisasi, dan pendampingan tenaga pengajar yang profesional. Dan 3) Berbasis potensi pendidikan dengan pengembangan bahan ajar tematik saintifik berbasis kearifan lokal dalam meningkatkan ketrampilan literasi.

\section{HASIL DAN PEMBAHASAN}

Pelaksanaan kegiatan Pengabdian Kemitraan Masayarakat (PKM) dilakukan mulai Maret 2019 dengan berbagai macam tahapan. Tiap tahap kegiatan pengabdian diperoleh hasil dan pembahasan sebagai berikut: 


\section{Kegiatan sosialisasi}

Sosialisasi sebagai tahap awal pada kegiatan pengabdian kali ini. Sosialisasi diberikan kepada masyarakat di sekitar barak sosial Desa Demaan Kudus. Pada kegiatan sosialisasi yang dihadiri 35 orang disampaikan tentang serangkaian kegiatan Pengabdian Kemitraan Masyarakat (PKM) yang akan dilaksanakan oleh Dosen FKIP UNISSULA. Diantaranya pelatihan dan bimbingan belajar bagi anak-anak jalanan yang bertempat tinggal di Barak Sosial Desa Demaan Kudus. Dalam pendampingan belajar bertujuan untuk meningkatkan ketrampilan literasi. Sosialisasi juga disampaikan kepada ketua RT setempat yaitu RT 03 RW 04 yaitu Bapak Misbah dan RT 04 RW 04 yaitu Bapak Santoso. Selain itu, kegiatan ini juga disampaikan Kepada kepala Desa Demaan Kudus yaitu Bapak Sugiyono, A.Md dan beliau memberikan dukungan terhadap kegiatan ini karena secara tidak langsung membantu pemerintah desa dalam meningkatkan kemampuan di bidang pendidikan dan sosial.

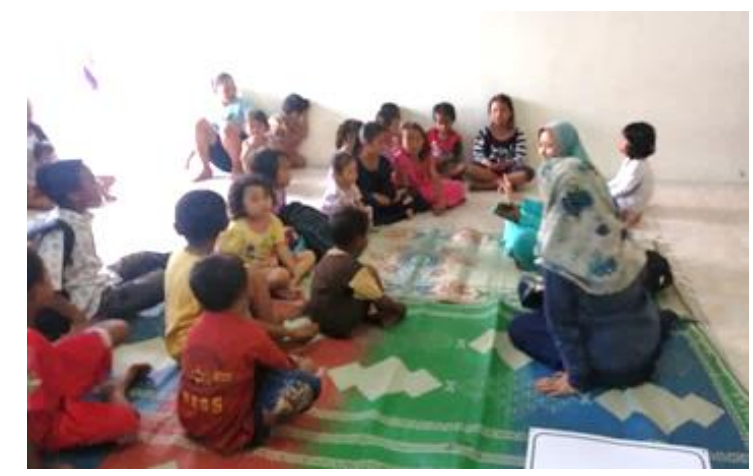

Gambar 1. Salah satu kegiatan pada tahap sosialisasi PKM (Dok.2019)

Sosialisasi kepada masyarakat disampaikan dengan beberapa metode seperti ceramah, motivasi, dan Tanya jawab. Adapun respon masyarakat sangatlah baik. Mereka menyambut dengan senang program ini karena kegiatan ini sangat bermanfaat terutama dalam membantu anak-anak mereka dalam belajar. Mendapat bimbingan belajar cumacuma dan bahan ajar serta pembelajaran yang menyenangkan bagi anakanak. Motivasi yang diberikan terutama tentang pentingnya pendidikan bagi mereka. Tim pengabdian juga menyampaikan motivasi agar anakanak mempergunakan waktu sebaik mungkin, tidak keluyuran di jalan raya, jangan salah bergaul dengan teman. Dan juga disampaikan akan pentingnya anak-anak mempunyai ketrampilan literasi yaitu ketrampilan membaca dan menulis. Sebagaimana pendapat Suragangga, I.M.N (2017) yang menyatakan bahwa kebiasaan membaca harus selalu dibiasakan mulai sejak dini karena keterampilan membaca dapat meningkatkan kemampuan seseorang untuk memahami berbagai konsep dengan mudah 


\section{Pelatihan Literasi}

Salah satu kegiatan pada pengabdian ini adalah adanya pelatihan literasi. Pada pelatihan literasi disampaikan tentang materi teknik membaca dan menulis. Anak-anak diberikan pengetahuan tentang teknik membaca permulaan, membaca cepat, menulis kalimat, menulis sesuai ejaan yang berlaku (EYD) dan seterusnya. Selain dari narasumber, materi tentang literasi juga disampaikan oleh anggota tim pengabdian sebagai pakar bahasa yaitu Leli Nisfi S, M.Pd dan Yulina Ismiyanti, M.Pd sebagai pakar Pendidikan Dasar. Anak-anak sangat antusias pada pelatihan tersebut.

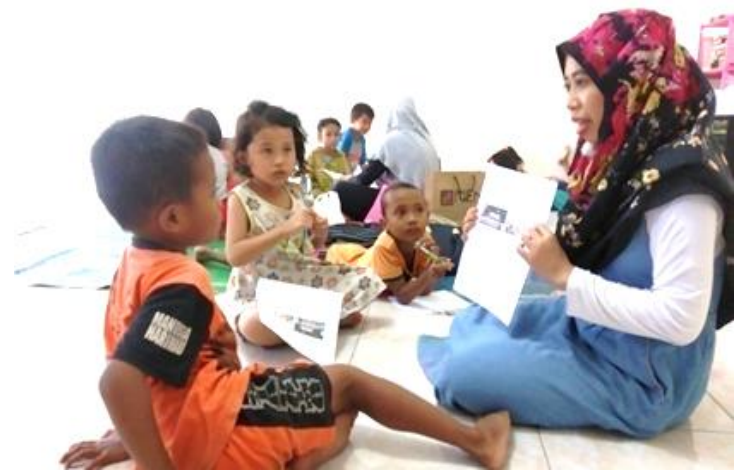

Gambar 2. Bentuk kegiatan literasi di Lokasi Pengadian (Dok.2019)

Literasi yang digalakkan pada pengabdian ini berbasis kearifan lokal. Jadi bacaan dan menulis melalui karangan pendek bertemakan tentang kabupaten Kudus. Anak-anak jalanan pastinya tidak asing dengan prosesi ziarah, dhandangan, menara kudus dan lain sebagainya. Karena seringnya anak-anak memanfaatkan event ini untuk aktivitas mereka. Maka dalam melatih literasi, hal ini membuat anak-anak semakin tertarik baik untuk membaca maupun menulis. Harapannya dapat memeberikan kesadaran kepada anak-anak akan pentingnya literasi sehingga dapat mensukseskan Gerakan Literasi Bangsa (GLB).

\section{Pendampingan Belajar}

Pada kegiatan pendampingan belajar dilakukan dua kali pertemuan tiap minggunya. Kegiatan ini dimulai pada bulan Mei 2019 dan akan selesai pada bulan Juli 2019. Pendampingan dibantu juga oleh segenap mahasiswa FKIP UNISSULA dan dikoordinir oleh ketua tim pengabdian yaitu Nuhyal Ulia, M.Pd. Anak-anak yang mengikuti bimbingan belajar mayoritas di usia SD kelas 1 sampai dengan 5. Bentuk kegiatannya adalah pendampingan literasi. Kehadiran anak-anak pada kegiatan ini pasang surut namun antusias sangatlah tinggi. Mereka selalu memperhatikan materi dan arahan dari tutor. Pada awal pertemuan 
jumlahnya masih sedikit namun pada pertemuan berikutnya sampai pada 26 anak mengikuti bimbingan belajar.

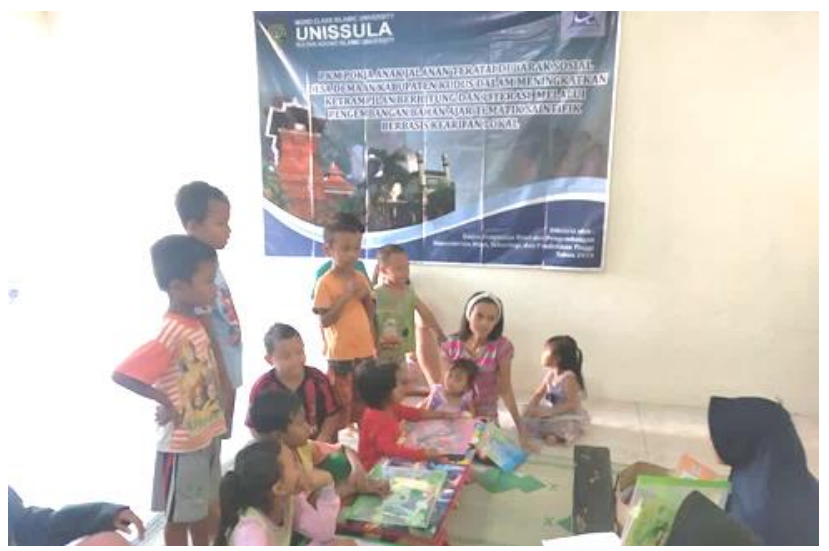

Gambar 3. Kegiatan Bimbingan Belajar bagi anak-anak jalanan

Pada awal pembelajaran, anak-anak juga dibimbing mengaji atau membaca Al Qur'an. Anak-anak juga diberikan lembar kerja terkait literasi saat pendampingan. Seperti pemahaman terhadap bacaan terkait kearifan lokal, menulis kalimat pendek dari sebuah gambar, dan bahkan sampai dengan membuat karangan deskripsi. Seperti yang telah disampaikan pada pendahuluan, bahwa anak-anak masih memiliki kemampuan literasi yang rendah. Kemampuan memahami bacaan masih kurang, menulis kalimat masih belum baik. Dari kegiatan pendampingan yang rutin dilaksanakan anak-anak menunjukkan peningkatan kemampuan literasi yang signifikan. Sebagaimana dapat dilihat pada gambar berikut tentang salah satu hasil pekerjaan anak terkait literasi pada awal pertemuan.

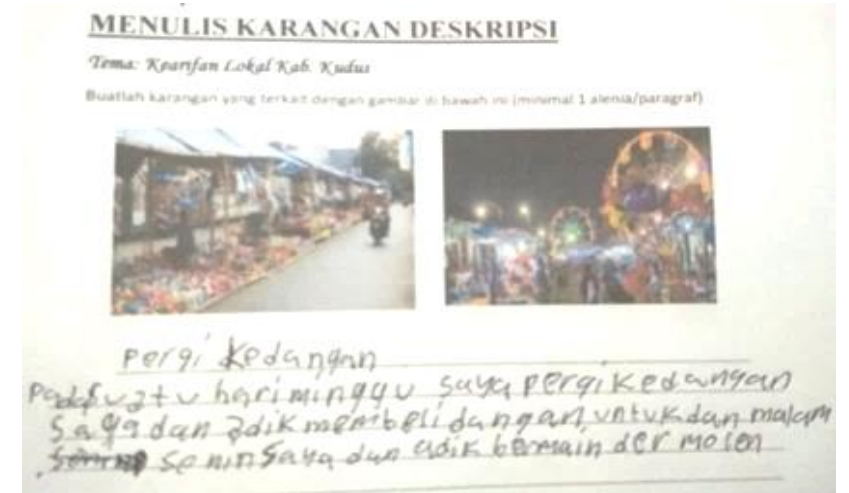

Gambar 4. Kemampuan literasi pada awal pendampingan 
Berdasarkan gambar 4 diatas, dapat dilihat bahwa hasil pekerjaan anak dengan inisial PA yang sudah duduk di kelas 5 SD masih mempunyai kemampuan menulis yang demikian. Penulisan belum sesuai dengan EYD, tata tulis mengabaikan spasi, belum dapat menyusun kalimat yang baik. Padahal pemahaman EYD diharapkan sedini mungkin sebagaimana pendapat Rahmaningsih, P. (2016) yang mengatakan bahwa penggunaan ejaan yang tepat merupakan dasar dari penggunaan bahasa Indonesia yang baik dan benar. Hal ini menjadi permasalahan yang di alami oleh rata-rata anak-anak jalanan. Setelah dilakukan beberapa pertemuan, hasil monitoring dan evaluasi menunjukkan adanya perkembangan yang signifikan. Dari hasil kegiatan pendampingan dapat disampaikan sebagaimana tabel 1 di bawah ini.

Tabel 1

Evaluasi Selama Pendampingan

\begin{tabular}{llc}
\hline & \multicolumn{1}{c}{ Indikator } & Target Capaian \\
\hline 1 & Tingkat Kehadiran Peserta & $75 \%$ \\
2 & Materi literasi yang disampaikan & $100 \%$ \\
3 & Pemahaman peserta terhadap materi literasi & $\geq 25 \%$ \\
\hline
\end{tabular}

Hasil kegiatan sampai dengan laporan kemajuan ini dibuat didapatkan bahwa anak-anak jalanan di Barak sosial Desa Demaan memberikan respon yang baik terhadap kegiatan ini. Kegiatan yang telah dilakukan yakni pemberian materi tentang literasi baik membaca maupun menulis. Dengan demikian didapatkan hasil bahwa sampai dengan pelaporan kemajuan ini dibuat telah mencapai $70 \%$ dari target yang akan dicapai dari kegiatan ini. Peserta baik anak-anak maupun orang tua dan masyarakat sekitar memberi respon yang baik pada kegiatan ini. Namun kami belum merekapitulasi daftar hadir peserta dan evaluasi kemampuan peserta.

\section{KESIMPULAN}

Berdasarkan hasil dan pembahasan, dapat disimpulkan bahwa Kegiatan Pengabdian Kepada Masyarakat mendapat respon positif dari semua pihak sehingga dalam kegiatannya dapat dilaksanakan sesuai jadwal yang sudah disepakati. Kemampuan literasi pada anak-anak jalanan mulai terlatih melalui kegiatan pengabdian dengan berbantuan bahan ajar tematik saintifik berbasis kearifan lokal. Harapannya kegiatan pengabdian masayarakt dapat dikembangkan lagi untuk peningkatan kompetensi yang lebih. seperti literasi berbasis teknologi digital. 


\section{UCAPAN TERIMA KASIH}

Kami menyampaikan terimakasih yang sebesar-besarnya kepada Direktorat Riset dan Pengabdian Masyarakat Dirjen Riset dan Pengembangan Kementerian Riset, Teknologi, dan Perguruan Tinggi Republik Indonesia atas persetujuan pendanaan dalam kegiatan Pengabdian Kepada Masyarakat (PPM) melalui Program Kemitraan Masyarakat (PKM) tahun 2019. Dengan nomor kontrak 448/B.1/SA-LPPM/VII/2019. Ucapan terima kasih sebesarbesarnya juga kami sampaikan kepada Universitas Sultan Agung (UNISSULA), LPPM UNISSULA, FKIP UNISSULA, Kepala Desa Demaan Kudus, Kelompok mahasiswa yang sudah membantu terlaksananya kegiatan pengabdian kepada masyarakat ini.

\section{DAFTAR RUJUKAN}

Ajisuksmo,C. (2012). "Faktor-Faktor Penting dalam Merancang Program Pendidikan Luar Sekolah untuk Anak Jalanan dan Pekerjaan Anak," Makara, Sos. Hum., vol. 16, no. 1, pp. 36-48.

Kemendikbud. (2016). "Pedoman Gerakan Nasional Literasi Bangsa," pp. 1-4. Rahmaningsih, P. (2016). Mengajarkan Ejaan pada Siswa Sekolah Dasar. Jurnal Ilmiah Guru Caraka Olah Pikir Edukatif, 20(1).

Suragangga, I. M. N. (2017). Mendidik lewat literasi untuk pendidikan berkualitas. Jurnal Penjaminan Mutu, 3(2), 154-163.

Tohir,M \& Jember. (2016). "Hasil PISA Indonesia Tahun 2015 Mengalami Peningkatan Hasil,".

Yunda ,P (2010). "Self-concept of Street Children," J. Transdisiplin Sosiologi, Komunikasi, dan Ekol. Mns., vol. 4, no. 2, pp. 255-27. 